\title{
Primary competencies for secondary school: psychological features of successful learning at transition grades
}

\author{
Maria Yanishevskaya ${ }^{1,2}$, Elena Vysotskaya $^{1}$, and Anastasia Lobanova ${ }^{*}$ \\ ${ }^{1}$ Psychological Institute of Russian Academy of Education, Laboratory of the Junior School Student \\ Psychology, Moscow, Russia \\ ${ }^{2}$ Moscow City University, Directorate of Educational Programs, Moscow, Russia
}

\begin{abstract}
As the transition period from primary to secondary education is difficult for many students, our strive is to study the psychological features, which may scaffold student's promotion and provide for future successful learning. We consider the educational media to be a complex system of psychological features, which depend on the content of education and the way, in which the educational process is organized. The "activity-and-content oriented" educational media devised after theoretical principles of the Developmental Instruction (Davydov), according to our hypothesis, provides sound bases for primary competencies formation, which are vital for secondary education. To test this assumption, we have diagnosed the quality of reflection, analysis, planning, model-acquisition and model-application, achieved by 204 students from two different educational media ("activity-and-content oriented" and "knowledge oriented"). For assessment purposes two diagnostic tools were used: "Transpositions" and "Moon" test. Both tests exploited contexts, which were unfamiliar to both groups of students. The results show, that students from the "activity-and-content" oriented educational media performed significantly better in most cognitive primary concepts. We consider these findings to support our major hypothesis, that educational media is a powerful source to scaffold students' primary competencies' formation, which in its turn provides for successful learning in secondary school. Keywords: educational media, primary competencies, transition period, assessment.
\end{abstract}

\section{Introduction}

Successful learning in school depends on a number of factors, among which psychological readiness for education is one of the most important. Though it is mostly associated with the first year of school education, many psychological and pedagogical problems at the transition period from elementary to secondary education also demand thorough study [13]. Thus, researchers also study psychological readiness for secondary education and suggest strategies to overcome the difficulties of this period. For example, social and emotional readiness may be achieved by inviting primary students to secondary school

\footnotetext{
*Corresponding author: andelobanova@yandex.ru
} 
classes within "shared learning days" [4]. Another way is to train students' leadership, communicative skills and self-confidence in primary school, and to provide students with the experience of personal success [5-7]. Evaluation of students' emotional state, concerns and expectations at the transition period is in the focus of many studies [8-10].

However, readiness "of a character" is not the only instrument to achieve success in one's learning activity in secondary education [11]. For example, there is an urgent need for modelling skills: due to the complexity and scope of concepts, which are to be acquired in the 5th grade, it is not enough to merely remember a diagram or a definition to be sufficient [12]. Students, who have demonstrated high level of modelling skills appeared to be more successful in the secondary education.

We consider cognitive competencies (both: concerning some specific domain or more general ones) to be a substantial part of the psychological readiness for secondary education. For the purpose of this study we assess analysis, reflection, planning and modelling skills. These competencies are recognized by most psychologists and educators as crucial. For example, Russian federal state educational standards [13] emphasize the ability to create, apply and transform symbolic representations, models and schemes while solving learning tasks as one of the crucial results of primary education.

We base on the assumption that the formation of the listed primary competencies provides for future promotion in secondary education. Thus, our major question is to identify the necessary psychological conditions that scaffold these competencies' formation. In this study we have focused on the educational media as a set of psychological features, based on the way of organization of learning activity and the content of education. We have assessed students from two "educational media".

The "activity-and-content oriented" media was devised within the Cultural-Historical Approach [14] framework and afterwards within Developmental Instruction Theory [15]. Students' promotion within this media is based on testing and assimilating ways and means to solve specially designed learning tasks within some practical narrative. Our hypothesis is, that this media scaffolds formation of primary competencies, which are most crucial for secondary education: modelling skills, analysis, reflection and planning.

The alternative media, which we may define as "knowledge oriented" exploits the approach "from simple to complex" and expects to form associations between pieces of information, assimilated by students. To support the assimilation process, this educational media emphasizes the necessity of systematic and consistent material presentation and explanation. Students' actions can be described thus in terms of operations with information: definition, systematization, analysis, reproduction, etc.

Is the formation of primary competencies significantly related to the educational media? - was our research question.

\section{Methods}

To evaluate initial primary competencies, we have used two diagnostic tests:

"Transpositions" [16] and "Moon" [17].

In the "Transpositions" test students are to swap figures in their slots thus their positions would fit the positions of numbers in the template (see Fig. 1). Students have to solve tasks mentally - they are restricted from taking any notes, except for writing an answer. They have to take one, two or even three steps to reach the answer. 


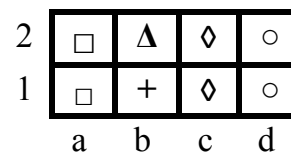

$\underline{\mathrm{N} 4}$

$2 \mathrm{~d}$

\begin{tabular}{|l|l|l|l|}
\hline 9 & 7 & 4 & 8 \\
\hline 9 & 7 & 5 & 8 \\
\hline
\end{tabular}

Fig. 1. "Transpositions", Task 4. Reach the positions in the template in two steps.

There are three groups of tasks, which were designed to evaluate three initial competencies. The first set aims to assess the quality of reflection: how does a student extract the solution patterns from the tasks? The key task here is to compare the tasks solved. The second set of tasks aims to evaluate analysis: these tasks differ from the starting set and demand to adapt the solution pattern to new conditions. The third group of tasks is aimed to assess the ability to plan: these tasks demand tricky transpositions or the result is to be achieved in three steps.

Students' performance in these three sets were then evaluated by experts, who attributed patterns of performance within each set of tasks to three levels of the corresponding competency: " 0 "- the competency is not formed; " 1 "- the competency is performed "formally", it is guided with external, irrelevant characteristics; "2" - means, that students employ "theoretical" way of solving problems (extracting essential characteristics of the objects).

"Moon" test contains a text and a series of tasks referring to it. The text describes "moon dial" - an instrument, which is totally new for students (Fig.2). It is designed to "count" weeks within a month (for example, weeks that passed, or weeks left). The text contained hints and direct references on how to use them. Five tasks, designed to evaluate model-assimilation, appealed to the moon-dial explicitly ("Show new moon on the moondial, please"). The instruction for the moon dial was to be extracted from the text. There was also a set of three tasks, which referred to the model implicitly: "Draw the moon as it would look like three weeks before full moon" - these tasks were to evaluate modelapplication. Students could solve them only using the moon dial, but the instruction did not demand to use it directly.

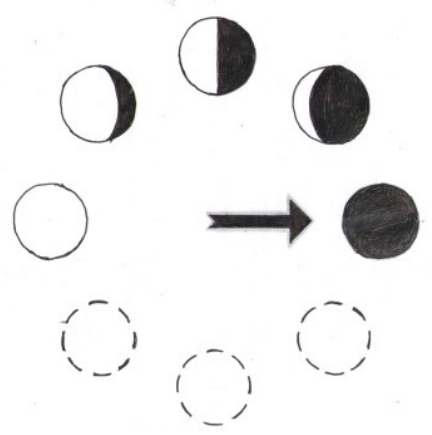

Fig. 2. The model, introduced in the "Moon" test.

Sample characteristics: 204 students ( $5^{\text {th }}$ grade, 11-12 years old) from two urban schools participated in the study.

EM1: "Activity-oriented" Educational media (the school is working after the Developmental Curricula) - 63 students.

EM2: "Knowledge-oriented" Educational media (the school is working after "traditional" curricula) - 141 students. 


\section{Results}

Figure 3 demonstrates the comparison of students' performance in two groups according to the three primary competencies, diagnosed in "Transposition" test.

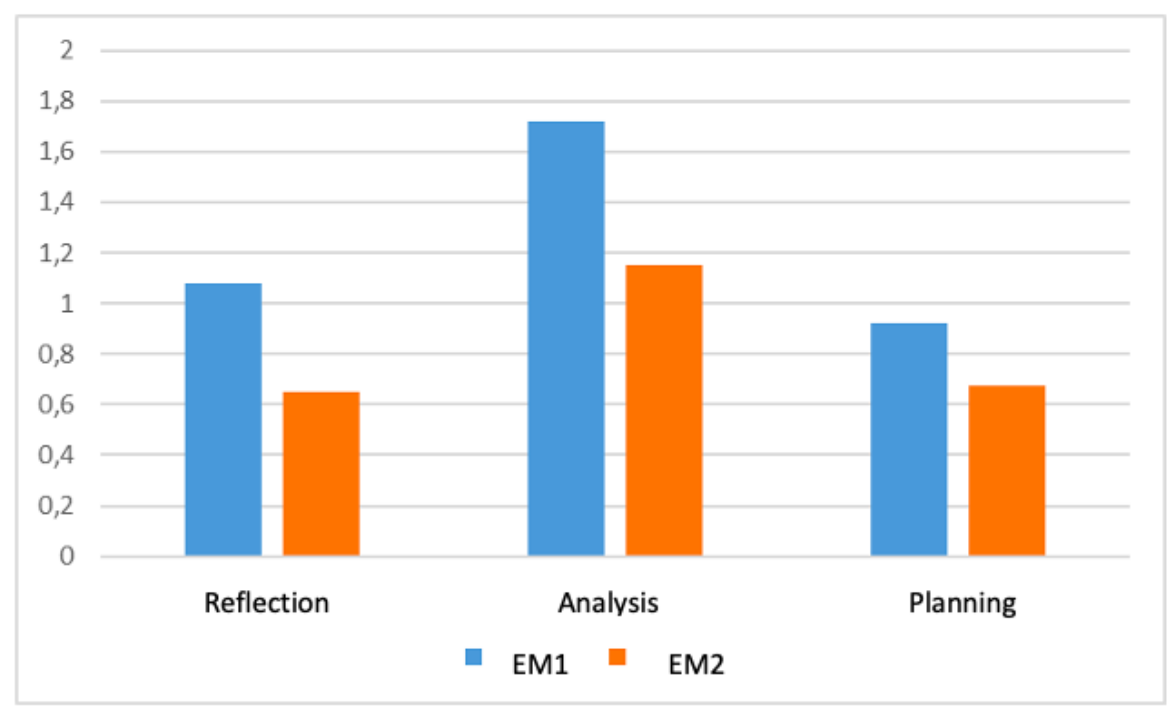

Fig. 3. The comparison of the quality of three primary competencies across two types of educational media (according to the expert evaluation of students' performance).

Differences were analyzed with Mann Whitney test: they appeared to be significant $(p<0.01)$ in Reflection and Analysis $\left(U_{r}=643\right.$ and $U_{a}=619$ accordingly). Students from the "activity-and-content oriented" media also performed better in the tasks concerning planning competency, but the difference is not significant $\left(\mathrm{U}_{\mathrm{m}}=819 ; \mathrm{p}=0.141\right)$.

For the "Moon" test we performed the analysis of the test score reliability. Cronbach's alpha for the model-acquisition tasks (0.703) and for model-application tasks (0.711) allows us to use total score of the whole set of tasks to assess corresponding competencies.

Table 1. Comparison of modelling skills between students from two educational media. Percent of successfully accomplished tasks.

\begin{tabular}{|c|c|c|}
\hline & model-acquisition & model-application \\
\hline EM 1 & $62 \%$ & $52 \%$ \\
\hline EM 2 & $17 \%$ & $11 \%$ \\
\hline & $\mathrm{p}<0.01$ & $\mathrm{p}<0.05$ \\
\hline
\end{tabular}

The results of the "Moon" test in the Table 1 also show, that students from "activityand-content oriented" educational media performed better than students from "knowledge oriented" educational media in both aspects: model-acquisition and model-application.

\section{Discussion}

The significant difference in cognitive primary competencies (reflection, analysis, modelacquisition and model-application) of 5th-graders supports our major hypothesis, that the formation of primary competencies depends on the type of the educational media.

The comparison of the level of cognitive competencies demonstrated by students from two different educational media shows, that most students from "content-and-activity 
oriented" media extract the pattern of solution based on the formal characteristics, whereas students from "knowledge oriented" media often fail to extract any pattern. The ability to analyse the task is based on essential characteristics for students from EM1, and on formal characteristics for students from EM2.

As we analyse the results of "Moon" test, we conclude, that in both samples 5th-graders perform better in the tasks that test how the model-mean is assimilated, than in the tasks, that refer to the model indirectly, but cannot be solved, if the model-mean is not used. Indeed, these assignments are considerably difficult for oral solution based on the information about moon phases. They demand using "Moon dial" consciously. This result was much expected.

Yet further analysis convinced us, that the decrease in these two samples was of different nature. We have found, that the correlation between individual performance in the two sets (model-acquisition and model-application) was significant for EM1 group (Pearson's correlation coefficient $=0.417 ; \mathrm{p}<0.01$ ); and was not significant for EM2 group (Pearson's correlation coefficient $=0.307 ; \mathrm{p}=0.053$ ). This way the efficiency in modelassimilation tasks did not lead students in "knowledge oriented" educational media to success in model application. In fact, their performance in the tasks of the second part is close to the probability to guess the answer. Thus, we can suggest, that for EM2 group students the "Moon dial" has not become a cultural mean for mediating orientation process even when it is treated correctly as an object.

\section{Conclusion}

Our results show significant differences in cognitive primary competencies of 5th-graders depending on the type of the educational media. We assume, that the "content-and-activity oriented" media provides for better results in terms of cognitive reflection, analysis, planning capacity, modelling skills.

"Knowledge oriented" media is aimed at acquisition and mastering skills to solve problems according to problem-types - thus, students may appear to be more sufficient in standard tests, than students from "activity-and-content oriented" educational media. But initial competencies, which are considered nowadays to be essential, are thus left unattended - though they still can be acquired due to personal students' (and their family's) efforts. At the same time providing complete and sound orientation basis is the basic principle for "activity-and-content oriented" educational media.

Moreover, whether a student has come upon adequate orientation or invents some "round-about" way, cannot be diagnosed by usual written tests with the same typical tasks. However, when students face new types of problems and new topics, those, who relied on "round-about" ways, have to invent new techniques. With every step in education it becomes more difficult. Meanwhile, those students, who have acquired adequate orientation basis, are more likely to be sufficient when the circumstances change. They need to adjust the acquired means of orientation, but the circumstances do not appear totally new for them. And even if they do, the previous experience of conscious working mediated with cultural means, may help. These two aspects - general orientation basis for some domain and a general attitude to learning - comprise cognitive meta-subject results and need to be addressed in future studies.

Creating educational media that would scaffold formation of primary competencies is still a challenge and a beacon for educators, psychologists and curriculum designers. We assume, that "activity-and-content oriented" media, devised within the Developmental Instruction, is the first step in this direction. 


\section{References}

1. M. van Rens, C. Haelermans, W. Groot, H. M. van den Brink, Adolescent Research Review, 3(1), 43-56 (2018). http://dx.doi.org/10.1007/s40894-017-0063-2

2. A. Denisova, Izvestia: Herzen University Journal of Humanities \& Sciences, 142, 83$91(2011)$

3. T.E. Virtanen, K. Vasalampi, M. Torppa, M.K. Lerkkanen, J.E. Nurmi, Learning and Individual Differences, 69, 138-149 (2019). https://doi.org/10.1016/j.lindif.2018.12.001

4. K. Kerr, School Science Review, 98(362), 27-32 (2016)

5. K. Hawk, J. Hill, Transition traumas, traps, turning points and triumphs: Putting student needs first, in Proceedings of Way Forward for Secondary Education Conference, 18-20 April 2004, Wellington, New Zealand (2004). Accessed on: December 16, 2020. [Online]. Available: http://educationgroup.co.nz/wpcontent/uploads/2016/04/Transition-traumas-traps-turning-points-and-truimphs.pdf

6. S. Eskelä-Haapanen, K. Vasalampi, M.K. Lerkkanen, Scandinavian Journal of Educational Research (2020). https://doi.org/10.1080/00313831.2020.1791248

7. A. Sviyagina, T. Knyazeva, Razvitiye kommunikativnykh kachestv shkol'nikov kak usloviye uspeshnoy adaptatsii pri perekhode v srednyuyu shkolu [The development of the communicative qualities of schoolchildren as a condition for successful adaptation during the transition to secondary school], in Proceedings of the XIII Russian scientific-practical conference of young researchers Scientific creativity of youth as a resource for the development of society, Minin Nizhny Novgorod State Pedagogical University, 24 April 2018, Nizhny Novgorod, Russia (2018)

8. M. Röder, A.R. Müller, International Journal of Educational Psychology, 9(1), 82-102 (2020). http://dx.doi.org/10.17583/ijep.2020.4463

9. F. Rice, N. Frederickson, J. Seymour, British Journal of Educational Psychology, 81(2), 244-263 (2011). https://doi.org/10.1348/000709910X519333

10. M.S. Tvedt, E. Bru, T. Idsoe, Scandinavian Journal of Educational Research, 1-22 (2019). https://doi.org/10.1080/00313831.2019.1659401

11. N. Lebedeva, Psikhologicheskaya gotovnost' mladshikh shkol'nikov ko vtoroy stupeni obshchego obrazovaniya [Psychological readiness of primary schoolchildren for the second stage of general education], Thesis (Lenin Moscow State Pedagogical University, Moscow, 1996)

12. G. Vergeles (Ed.), Mladshiy shkol'nik: formirovaniye i razvitiye yego lichnosti [Junior student: the formation and development of his personality] (Publishing house of the Russian State Pedagogical University named after A. I. Herzen, Saint Petersburg, 2002)

13. A. Kazakova (Ed.), Federalnyy gosudarstvennyy obrazovatelnyy standart nachalnogo obshchego obrazovaniya. FGOS [Federal state educational standard of primary general education. FSES] (Prosveshenije, Moscow, 2019)

14. L.S. Vygotsky, Thought and language (MIT Press, Cambridge, MA, 1986)

15. V.V. Davydov, Problems of developmental instruction: a theoretical and experimental psychological study (Nova Science Publishers, Hauppauge, 2008)

16. I. Ulanovskaya (Ed.), Otsenka metapredmetnykh kompetentsiy vypusknikov nachal'noy shkoly [Assessment of metasubject competences of primary school graduates] (Moscow State University of Psychology and Education, Moscow, 2015) 
17. E. Vysotskaya, I. Ulanovskaya, M. Yanishevskaya, Formation of metasubject educational results: age dynamics [Formirovaniye metapredmetnykh obrazovatel'nykh rezul'tatov: vozrastnaya dinamika], in Proceedings of the conference "Personality, intelligence, metacognition: research approaches and educational practices", Kaluga State University K.E. Tsiolkovsky, 19-21 April 2018, Kaluga, Russia (2018) 